\title{
A Retrospective Study of Patients with Acute Pancreatitis in an Internal Medicine Clinic
} Akut Pankreatitli Hastaların Geriye Dönük İncelenmesi

\section{(D) Belgin Boran İncebacak¹, (D Kader İrak², (D) Ömür Tabak¹, (D Abdülbaki Kumbasar¹}

${ }^{1}$ Kanuni Sultan Süleyman Training and Research Hospital, Clinic of Internal Medicine, İstanbul, Turkey

${ }^{2}$ Kanuni Sultan Süleyman Training and Research Hospital, Clinic of Gastroenterology, İstanbul, Turkey

\section{Abstract}

Objective: Acute pancreatitis (AP) is the rapid inflammation of the pancreas which may be life threatening, even though the disease course may range from mild to severe. We sought to investigate the characteristics of cases followed with a diagnosis of AP at our clinic.

Method: Patients diagnosed and followed with AP from 2015 to 2017 at the Istanbul Kanuni Sultan Süleyman Training and Research Hospital were analyzed retrospectively. Demographic features, etiological factors, duration of hospitalization, antibiotic usage and complications were investigated.

Results: Of the 160 patients with AP, 65 (40.6\%) were male and 95 (59.4\%) were female. The mean age of the patients was $56.2 \pm 19.1$ years. At hospital admission, fever and abdominal pain were observed in $5 \%$ of the patients, abdominal pain and itching were present in $1.3 \%$, while abdominal pain and jaundice were reported in $3.8 \%$. Etiology of AP was defined as gallstones in $42.5 \%$, alcohol in $4.4 \%$, hyperlipidemia in $0.6 \%$, posttraumatic causes (including endoscopic retrograde cholangiopancreatography) in 5.6\%, drugs in 3.8\%, malignancy in $1.3 \%$, and autoimmunity in $\% 3.8$, and the remaining $38 \%$ were evaluated as idiopathic pancreatitis. Three patients with cardiac complications were either admitted to the intensive care unit (2 patients) or died (1 patient).

Conclusion: Gallstone-related AP was determined to be the most common cause of AP in this study, and idiopathic causes were shown in the second rank. Endoscopic retrograde cholangiopancreatography should be planned if there is clinical deterioration and cholangitis. Serious complications (such as cardiac) may develop in patients defined to have mild disease. Thus, clinicians must be aware of this possibility and should be on high alert for possible cardiac complications which may lead to mortality or intensive care admission.

Keywords: Acute pancreatitis, etiology, retrospective analysis

\section{Öz}

Amaç: Olguların seyri hafif ve ağır arasında değişkenlik gösterse de, akut pankreatit (AP) hayatı tehdit etme intimali olan akut bir pankreas iltihabıdır. Bu çalışmada kliniğimizde AP tanısı ile takip edilmiş olguların irdelenmesi amaçlandı.

Yöntem: İstanbul Kanuni Sultan Süleyman Eğitim ve Araştırma Hastanesi'nde 2015-2017 yılları arasında takip edilmiş olan AP olguları geriye dönük incelemeye alındı. Hastaların demografik özellikleri, etiyolojik faktörler, yatış süresi, antibiyotik kullanımı ve komplikasyonları araştııılı.

Bulgular: Akut pankreatitli 160 hastanın 65'i erkek (\%40,6), 95'i kadındı $(\% 59,4)$. Yaş ortalaması 56,2 $\pm 19,1$ yıl idi. Olguların \%42,5'inde safra taşı, $\% 4,4$ 'ünde alkol, \%0,6'sında hiperlipidemi, \%5,6'sında post travmatik (endoskopik retrograd kolanjiopankreatografi dahil), \%3,8'inde ilaç, $\% 1,3$ 'ünde malignite, \%3,8'inde otoimmün ve geri kalan \%38'inde idiyopatik AP geliştiği tespit edildi. Hastaneye başvuru sırasında olguların \%5'inde ateş ve karın ağrısı, \%1,3'ünde karın ağrısı ve kaşıntı, \%3,8'inde karın ağrısı ve sarılık görüldü.

Sonuç: AP etiyolojisinde en sık safra taşı tespit edilmiş olup, idiyopatik nedenler ikinci sırada gelmektedir. Klinik kötüleşme ve kolanjit varsa endoskopik retrograd kolanjiyopankreatografi planlanmalıdır. Hafif seyirli olarak tanımlanan hastalarda da ciddi komplikasyonlar gelişebilir (örneğin; kardiyak). Klinisyenler, ölüm veya yoğun bakım ihtiyacına neden olabilecek kardiyak komplikasyonların gelişme ihtimaline karşı tetikte olmalıdırlar.

Anahtar kelimeler: Akut pankreatit, etiyoloji, retrospektif inceleme

Address for Correspondence: Kader İrak, Kanuni Sultan Süleyman Training and Research Hospital, Clinic of Gastroenterology, İstanbul, Turkey E-mail: drkaderirak@hotmail.com ORCID: orcid.org/0000-0002-0019-3207 Received: 18.07.2020 Accepted: 06.10.2020

Cite this article as: Boran İncebacak B, İrak K, Tabak Ö, Kumbasar A. A Retrospective Study of Patients with Acute Pancreatitis in an Internal Medicine. Bagcilar Med Bull 2020;5(4):193-198

${ }^{\circ}$ Copyright 2020 by the Health Sciences University Turkey, Bagcilar Training and Research Hospital Bagcilar Medical Bulletin published by Galenos Publishing House. 


\section{Introduction}

Acute pancreatitis (AP) is an inflammatory condition of the pancreas that has a broad clinical spectrum ranging from local injury to systemic inflammatory response syndrome and organ failure. It is a common gastrointestinal condition throughout the world, which challenges the healthcare system due to associated morbidity and treatment costs. The incidence is reported to be 5 to 30 per 100,000 population, and the average mortality rate is $5 \%$ but varies depending on the severity of cases (1).

The most common causes of AP include gallstones and alcohol, which are identified in up to $80 \%$ of cases. The rest of the cases are associated with less common causes such as drug reactions, pancreatic solid and cystic malignancies, and hypertriglyceridemia. Definitions of key terms were based on the 2012 Atlanta Classification of AP; Diagnosis of AP (two of the following) (2).

- Abdominal pain (acute onset of a persistent, severe, epigastric pain often radiating to the back)

- Serum lipase activity (or amylase) at least 3 times greater than the upper limit of normal

- Characteristic findings of AP on computed tomography (CT) or magnetic resonance imaging. Contrast-enhanced abdominal CT scan findings of acute interstitial edematous pancreatitis include focal or diffuse enlargement of the pancreas with heterogeneous enhancement with intravenous contrast. When contrast-enhanced CT is performed on three or more days after abdominal pain, necrosis, complications, and severity can be predicted (Table 1) (2).

The Ranson criteria is a scoring system that has been used frequently to evaluate AP severity. The most important disadvantage of the Ranson criteria is that it does not provide accurate information within the first 24 hours. Systemic inflammatory response criteria and bedside acute pancreatitis severity index (BISAP) criteria have been recommended for the first 24-48 hours in recent years (3). Although conservative treatments are very effective in mild cases, in severe AP, intensive care follow-up, broadspectrum antibiotic therapy, enteral feeding, endoscopic retrograde cholangiopancreatography (ERCP) and sphincterotomy may be required (4).

We have retrospectively analyzed the etiology of the patients followed-up with AP at our clinic in order to evaluate the frequency of various signs and symptoms at hospital admission, antibiotic use, complications, and prognosis.

\section{Materials and Methods}

The medical records of 160 patients hospitalized in the internal medicine clinic of our hospital between the years of 2015 and 2017 were analyzed retrospectively. Patients who were diagnosed with AP during the study period were included in the study. Their demographic characteristics, laboratory results and imaging findings were assessed and recorded.

The 2012 revision of the Atlanta Classification of AP was used for the diagnosis of AP (2). Briefly, the presence of 2 of the following 3 criteria was accepted as definite AP: (i) severe epigastric pain radiating to the back, (ii) an increase of at least 3-fold the upper reference value of amylase or lipase (in our hospital laboratory amylase $<100$, lipase $<60$ ) (iii) findings conclusive for AP on CT or magnetic resonance imaging. Ultrasonography (USG) evaluation was performed after emergency room admission in patients that required differential evaluation during diagnosis. Patients who were diagnosed without imaging findings and later developed non-mild AP also underwent imaging with CT.

At admission ( 0 hours) and at the $48^{\text {th }}$ hour, the severity of disease was classified according to the Ranson criteria and mild pancreatitis was defined in patients scoring $<3$ points, while severe pancreatitis was defined in patients with $\geq 3$ points. Also, the expected mortality rate was calculated via the BISAP criteria as $<1 \%$ for 0 points and $25 \%$ for 5 points. Then, the relationship between disease severity and etiological factors, age, gender, duration of hospitalization, antibiotic use, C-reactive protein (CRP) levels, and prognosis was examined.

\section{Statistical Analysis}

The Statistical Package for Social Sciences (SPSS) version 22.0 (SPSS Inc., Chicago, IL, USA) statistics software was used for all statistical analyses. The CRP values and duration of hospitalization were presented as mean \pm standard deviation. For categorical values, count (n) and percentage (\%) were used. The comparison of CRP values from admission to 48-hour results were performed with the related-samples Wilcoxon test. The results were interpreted according to the significance level of $\mathrm{p} \leq 0.05$.

\section{Results}

A total of 160 patients were included in the study, 95 (59.4\%) were female and 65 (40.6\%) were male. The mean age of the patients was 56.2 \pm 19.1 years. At hospital admission, fever and abdominal pain were observed in $5 \%$ of cases, 
abdominal pain and itching were present in $1.3 \%$, while abdominal pain and jaundice were reported by $3.8 \%$ of the patients.

In the current study group, gallstone-induced AP was observed in 68 (42.5\%) patients, idiopathic pancreatitis in
60 (37.5\%) patients, and alcohol-induced pancreatitis in 7 (4.4\%) patients. All patients with alcohol-induced AP were male. With regard to other causes, we found that druginduced AP was observed in 6 (3.8\%) patients, autoimmune AP in $6(3.8 \%)$ patients, traumatic AP in $9(5.6 \%)$ patients, hyperlipidemia-related AP in $1(0.6 \%)$ male patient, and

\section{Table 1. Radiological definition of acute pancreatitis}

\section{Interstitial edematous pancreatitis}

Acute inflammation of pancreatic parenchyma and peripancreatic tissues, but no necrosis. Criteria for contrast-enhanced computed tomography:

- Pancreatic parenchyma increases with intravenous contrast agent

- No signs of peripancreatic necrosis

\section{Necrotizing pancreatitis}

Inflammation associated with pancreatic parenchymal necrosis and/or peripancreatic necrosis

Contrast-enhanced computed tomography criteria:

- Absence of pancreatic parenchyma involvement with intravenous contrast agent and/or

- Presence of signs of peripancreatic necrosis

\section{Acute peripancreatic fluid collection}

Pancreatitis with interstitial edema and peripancreatic fluid without peripancreatic necrosis. Applies to peripancreatic fluid areas seen within the first four weeks without a pseudocyst.

Contrast-enhanced computed tomography criteria:

- Occurs in the case of interstitial edematous pancreatitis

- Homogeneous collection with liquid density

- Limited to normal peripancreatic facial planes

- No identifiable wall surrounding the collection

- Adjacent to the pancreas (no intrapancreatic extension)

\section{Pancreatic pseudocyst}

Maturation usually requires 4 weeks after the onset of acute pancreatitis; occurs after pancreatitis with interstitial edema.

This entity usually occurs more than four weeks after the onset of interstitial edematous pancreatitis to mature.

Contrast-enhanced computed tomography criteria:

- Well circumscribed, usually round or oval

- Homogeneous fluid density

- No non-liquid component

- Well-defined wall (ie, completely encapsulated)

- Maturation usually requires $>4$ weeks after the onset of acute pancreatitis; occurs after interstitial edematous pancreatitis

\section{Acute necrotic collection}

A collection containing variable amounts of both fluid and necrosis associated with necrotizing pancreatitis; the necrosis can involve the pancreatic parenchyma and/or the peripancreatic tissues

Contrast-enhanced computed tomography criteria:

- Occurs only in the setting of acute necrotizing pancreatitis

- Heterogeneous and non-liquid density of varying degrees in different locations (some appear homogeneous early in their course)

- No definable wall encapsulating the collection

- Location-intrapancreatic and/or extrapancreatic

\section{Walled-off necrosis (WON)}

A mature, encapsulated collection of pancreatic and/or peripancreatic necrosis that has developed a well- defined inflammatory wall. WON usually occurs $>4$ weeks after the onset of necrotizing pancreatitis.

Contrast-enhanced computed tomography criteria:

- Occurs only in the setting of acute necrotizing pancreatitis

- Heterogeneous and non-liquid density of varying degrees in different locations (some appear homogeneous early in their course)

- No definable wall encapsulating the collection

- Location-intrapancreatic and/or extrapancreatic 
malignancy related AP in $3(1.9 \%)$ patients (all male) (Table 2).

The patient with hyperlipidemia-related AP had a history of multiple attacks of pancreatitis. In 2 patients, AP had developed after ERCP intervention. Two of the patients with gallstone-induced pancreatitis were pregnant and had no complications. Drug-induced AP was seen in 6 (3.8\%) patients. The drugs thought to be responsible for AP development were sitagliptin, exanatide, carbamazepine, azathiopurine, and also HRT treatment.

In 86 cases (58.5\%), normal findings were seen in abdominal USG. In 49 cases (33.3\%), sludge or stones were detected in the biliary tract. It was noted that only $9(6.1 \%)$ patients' USG reports showed inflammatory findings in the pancreas (supporting AP diagnosis). The CT imaging results were conclusive for edematous pancreatitis in 106 (66\%) patients, while necrotizing pancreatitis was detected in $10(6.3 \%)$ patients. Local complications were detected in 14 patients $(8.8 \%)$. An ampulla tumor was detected in 1 patient. In total, 29 patients who had good clinical condition and demonstrated a regression of inflammatory markers did not undergo CT scan.

With regard to the Ranson criteria, 106 patients were expected to have good prognosis ( $<3$ points) with mild edematous pancreatitis, and 54 patients were expected to have poor prognosis ( $\geq 3$ points) with severe AP. When scores obtained from the BISAP criteria were assessed, we found that a patient with 5 points had died. In addition, among the 3 patients with 3 points, 2 were admitted to the intensive care unit and one was followed-up in the general surgery clinic with necrotizing pancreatitis.

The mean duration of hospitalization in our study was $6.31 \pm 4.68$ days. The antibiotics preferred during hospitalization were: ceftriaxone in $54.6 \%$, ceftriaxone and metronidazole in $16.6 \%$, and imipenem in $11.1 \%$.

Table 2. Etiological factors of acute pancreatitis

\begin{tabular}{lll} 
Etiology & $\mathbf{n}$ & $\%$ \\
\hline Gallstones & 68 & 42.5 \\
Idiopathic & 60 & 37.5 \\
Trauma & 9 & 5.6 \\
Alcohol & 7 & 4.4 \\
Drugs & 6 & 3.8 \\
Autoimmunity & 6 & 3.8 \\
Malignancy & 2 & 1.3 \\
Ampulla tumor & 1 & 0.6 \\
Hyperlipidemia & 1 & 0.6
\end{tabular}

With regard to the local and systemic complications of AP, we identified thrombocytopenia in 1 patient $(0.6 \%)$, respiratory system complications in 9 patients $(5.6 \%)$, hyponatremia in 1 patient $(0.6 \%)$, hypokalemia in 1 patient $(0.6 \%)$, and gastrointestinal bleeding in 1 patient $(0.6 \%)$. Furthermore, in 2 patients (1.2\%), pancreatitis caused diabetic ketoacidosis, while acute coronary syndrome occurred in 4 patients $(2.5 \%)$ and cardiac problems developed in 4 patients (2.5\%). A temporary increase in creatinine levels was detected in 2 patients $(1.2 \%)$ with chronic renal failure. Finally, ileus occurred in 1 patient (0.6\%) (Table 3).

The mean CRP levels at the time of hospitalization (39.5 \pm 63.6$)$ and at the $48 \mathrm{t}^{\mathrm{th}}$ hour $(106.1 \pm 108.2)$ were compared, demonstrating a statistically significant increase $(\mathrm{p}<0.05)$.

\section{Discussion}

The current study reports the frequency and distribution of the characteristics of patients diagnosed with AP at our center. A slight female predisposition was determined, the great majority of patients had gallstone-related or idiopathic AP, and alcohol-related AP was considerably rare compared to that in publications from other countries. The latter is a common finding in Turkish studies and is associated with lower alcohol consumption. The results for clinical findings, antibiotic use, prognosis and complications did not yield any noteworthy findings and were similar to previous studies.

In a study by Yalçin et al. (5) from Turkey, $67.5 \%$ of the patients were female, $32.5 \%$ were male and the mean age was $55.17 \pm 19.75$ (minimum: 18, maximum: 93) years. Apart from the slightly lower frequency of females in our study, the results were similar. With regard to etiology, Yalçın et al. (5) reported the three most common causes of AP as biliary pathologies $(70.1 \%)$, hyperlipidemia $(5.7 \%)$ and alcohol (4.8\%), while $16.1 \%$ of cases were classified as idiopathic (5). Alcohol-induced pancreatitis is common in western countries, whereas gallstone-related AP is almost

\begin{tabular}{lcc} 
Table 3. Systemic complications in acute pancreatitis \\
Complication & $\mathbf{n}$ & $\%$ \\
\hline Respiratory system & 9 & $5.6 \%$ \\
Renal complications & 6 & $3.75 \%$ \\
Gastrointestinal complications & 2 & $1.2 \%$ \\
Diabetic ketoacidosis & 2 & $1.2 \%$ \\
Cardiac problems & 4 & $2.5 \%$ \\
Hematologic complications & 1 & $0.6 \%$
\end{tabular}


always ranked in first place in our country (6). Gallstone pancreatitis is more common in women than in men and alcohol-induced pancreatitis is more common in men. In our country, alcohol-induced AP cases comprise around $10-15 \%$ of all pancreatitis cases (7). In the study by Gülen et al. (8), biliary causes represented $68.1 \%$ of the etiological distribution, alcohol was found in $14 \%$, other causes were $6.1 \%$ and idiopathic causes were $11.8 \%$. In the study by Demiral et al. (9), the most common cause was gallstones (80.9\%), followed by hyperlipidemia (4.5\%). These results are mostly similar to our findings and indicate the importance of gallstone-related and idiopathic AP development in our country. In a study in the United Kingdom, it was reported that approximately half of cases with AP originated from gallstones and a quarter from alcohol (10). In our study, we detected gallstone-related AP in $42.5 \%$ of cases and idiopathic pancreatitis in $38 \%$. The frequencies of other less-common etiologies were as follows: posttraumatic (5.6\%), drug-induced (3.8\%), alcohol-induced (4.4\%), autoimmune (3.8\%), malignancyrelated $(1.3 \%)$ and hyperlipidemia-related $(0.6 \%)$.

In the USA, it has been reported that $1-2 \%$ of AP cases are related to malignancies (11). Similarly, in our study, malignancy was detected in only $2(1.3 \%)$ cases. One of these patients had the Gray-Turner sign. Although this symptom is not specific, it is a symptom of retroperitoneal bleeding in pancreatic necrosis and has been reported to be detected in $1-3 \%$ of cases (12).

The sensitivity of USG in AP is estimated to be $75-85 \%$ (13). In our study, USG was normal in 86 cases (58.5\%) and gallstones or sludge in the biliary tract was detected in 49 cases (33.3\%). Even though 135 of the 160 patients had undergone USG after admission, we found that only a fraction $(6.1 \%)$ of the patients' diagnoses had been supported by USG findings. This is very low compared to the literature and may be due to the insufficiency of examination with USG in the emergency conditions and minimal changes in the pancreas in the acute period.

CT is considered as the most important diagnostic tool to assess diagnosis, prognosis and complications in AP. Imaging with CT can demonstrate $90-95 \%$ of pathologies that develop in AP. It must be noted that since pancreatic necrosis findings are evident after 48-72 hours, early CT may not be reliable. In our study, CT findings were normal in 42 patients (26.3\%) during the initial admission to the hospital. Complications were observed in CT in only 3 cases (1.9\%).
AP is a disease that has a mild course (self-limiting and returning to normal) in $70-80 \%$ of patients, while it is severe and progressive with high mortality in $20-30 \%$ (14). Necrotizing pancreatitis develops in $5-10 \%$ of all pancreatitis cases, which was similar to our finding of 6.3\%. Nine patients $(5.6 \%)$ experienced pleural effusion and 6 patients $(3.8 \%)$ experienced renal complications. Other studies have reported that acute kidney injury occurs in $3-15 \%$ of cases (15). It is obvious that the most mortal complications are cardiac complications, which were rather rare $(2.6 \%)$ in our study group. Although edematous pancreatitis was identified in these patients, 1 patient who died and 2 patients who were admitted to the intensive care unit had experienced serious cardiac problems. Another complication seen in AP is diabetic ketoacidosis, a condition that is within the differential diagnoses of AP and can also be observed as a complication.

The mean Ranson criteria score of the patients was $2 \pm 1.3$. Accordingly, 106 cases had expectation of good prognosis and 54 cases had expectation of poor prognosis. Alcohol-induced AP cases had been found to have a good prognosis expectation according to Ranson score. Alcohol-related etiology was seen as a major risk factor in the prognosis of pancreatitis in a study by Frey and colleagues (16). However, in meta-analysis conducted by De Bernardinis et al. (17), the Ranson score was suggested to be a weak marker in predicting the prognosis of pancreatitis. Although the number of patients in this study was limited, our findings also support the notion that the Ranson criteria may not be a good scoring system to determine prognosis in patients with AP. We believe clinicians must be aware of the possibility of rare but serious complications even in patients with mild disease, as demonstrated by our results.

According to a large epidemiological study conducted between 1988 and 2003 in the USA, the mean duration of hospitalization in patients with AP was 6.9 days (18). This is similar to our findings that showed a mean duration of hospitalization as $6.31 \pm 4.68$ days. In the same study from the USA, the mortality of disease was shown to have had a decreasing trend, from $12 \%$ to $2 \%$ (18). In the present study group, mortal disease had occurred in $1.6 \%$ of patients, indicating a continuation of this trend. The advances in medicine and patient care, in addition to the increased chance for intensive care admission (for patients with poor general condition), may be among the reasons for this low mortality rate. 


\section{Conclusion}

Gallstone-related AP was determined to be the most common cause of AP in this study, and our results showed a higher frequency in females. Although alcohol consumption-related AP frequency was lower compared to the literature, our results were in support of the majority of previous studies from Turkey. Although mortality rates have decreased throughout the past 2-3 decades, it is evident from our results that serious complications may develop in patients defined to have mild disease by various scoring criteria. Thus, clinicians must be aware of this possibility and should be on high alert for possible cardiac complications which may lead to mortality or intensive care admission.

\section{Ethics}

Ethics Committee Approval: The present study was conducted after being approved by the Local Ethics Committee of Bakırköy Dr. Sadi Konuk Training and Research Hospital, Istanbul, Turkey (reference no: 2017T234, date: 14/08/2017).

Informed Consent: This is a retrospective study.

Peer-review: Externally peer-reviewed.

\section{Authorship Contributions}

Concept: B.B.İ., K.İ., Ö.T., A.K., Design: B.B.İ., K.İ., Ö.T., A.K., Data Collection or Processing: B.B.I.., K.İ., Ö.T., A.K., Analysis or Interpretation: B.B.İ., K.İ., Ö.T., A.K., Writing: B.B.İ., K.İ., Ö.T., A.K.

Conflict of Interest: No conflict of interest was declared by the authors.

Financial Disclosure: The authors declared that this study has received no financial support.

\section{References}

1. Crockett SD, Wani S, Gardner TB, Falck-Ytter Y, Barkun AN. American Gastroenterological Association Institute Guideline on Initial Management of Acute Pancreatitis. Gastroenterology 2018;154(4):1096-1101.

2. Banks PA, Bollen TL, Dervenis C, Gooszen HG, Johnson JD, Sarr MG, et al. Classification of acute pancreatitis 2012: revision of the Atlanta classification and definitions by international consensus. Gut 2013;62(1):102-111.

3. Van Dijk SM, Hallensleben NDL, van Santvoort HC, Fockens P, van Goor H, Bruno MJ, et al. Acute pancreatitis: recent advances through randomised trials. Gut 2017;66(11):2024-2032.
4. Working Group IAP/APA Acute Pancreatitis Guidelines. IAP/ APA evidence-based guidelines for the management of acute pancreatitis. Pancreatology 2013;13(4 Suppl 2):e1-e15.

5. Yalçın MS, Kara B, Ölmez Ş, Yalaki S, Akçaer Öztürk N, Evren Taşdoğan B, et al. Akut Pankreatit Epidemiyoloji Güncellemesi: 335 Vakanın Retrospektif Analizi. Firat Tip Derg 2016;21(4):200203.

6. Tran DD, Cuesta MA. Evaluation of severity in paitents with acute pancreatitis. Am J Gastroenterol 1992;87(5):604-608.

7. Taşkın AK, Özaydın İ, Demiraran Y, Yaşar M. Batı Karadeniz Bölgesindeki Akut Pankreatitli Hastaların Retrospektif Analizi. Duzce Med J 2010;12(3):45-49.

8. Gülen B, Sonmez E, Yaylaci S, Serinken M, Eken C, Dur A, et al. Effect of harmless acute pancreatitis score, red cell distrubition width and neutrophil/lymphocyte ratio on the mor-tality of patients with on nontraumatic acute pancreatitis at the emergency department. World J Emerg Med 2015;6(1):29-33.

9. Demiral G, Yener O, Aksoy F, Çelik Y, Bayraktar B, Yllmaz A, et al. Akut pankreatitli hastalarımızın retrospektif olarak değerlendirilmesi Göztepe Tıp Dergisi 2011;26(1):4-9.

10. Beger HG, Rau B, Isenmann R. Prevention of severe change in acute pancreatitis: prediction and prevention. J Hepatobiliary Pancreat Surg 2001;8(2):140-147.

11. Sekimoto M, Takada T, Kawarada Y, Hirata K, Mayumi T, Yoshida $\mathrm{M}$, et al. JPN Guidelens fort the management of acute pankreatitis: epidemiology etiology, natural history and outcome predictors in acute pancreatitis. J Hepatobiliary Pancreat Surg 2006:13(1):10-24.

12. Dickson AP, Imrie CW. The incidence and prognosis of body wall ecchymosis in acute pancreatitis. Surg Gynecol Obstet 1984;159(4):343-347.

13. Goldacre NJ, Roberts SE. Hospital admissions for acute pancreatitis in an English population, 1963-98: database study of incidence and mortality. BMJ 2004;328(7454):1466-1469.

14. Slavin J, Ghaneh P, Sutton R, Hartley M, Rowlands P, Garvey C, et al. Management of necrotizing pancreatitis. World J Gastroenterol 2001;7(4):476-481.

15. Toskes PP, Greenberger NJ. Harrison Principles of Internal Medicine. 7th ed., 2010:20052011.

16. Frey CF, Zhou H, Harvey DJ, White RH. The incidence and casefatality rates of acute biliary, alcoholic, and idiopathic pancreatitis in California, 1994-2001. Pancreas 2006;33(4):336-344.

17. De Bernardinis M, Violi V, Roncoroni L, Boselli AS, Giunta A, Peracchia A. Discriminant power and information content of Ranson's prognostic signs in acute pancreatitis: a meta-analytic study. Crit Care Med 1999;27(10):2272-2283.

18. Fagenholz PJ, Castillo CF, Harris NS, Pelletier AJ, Camargo CA. Increasing United States hospital admissions for acute pancreatitis, 1988-2003. Ann Epidemiol 2007;17(7):491-497. 